\title{
UROLITHIASIS IN CHILDREN WITH SPINAL CORD INJURY ${ }^{1}$
}

\author{
By Jorge A. Tori, M.D., and L. S. Kewalramani, M.D., M.S.Orth. \\ Texas Institute for Rehabilitation and Research and Baylor College of Medicine Houston, \\ Texas 77030, U.S.A.
}

Abstract. .In the literature there is a paucity of references on urolithiasis in children with spinal cord injury. In this paper 28 cases of urolithiasis in 97 children with spinal cord injury are analysed. An attempt is made to evaluate the role of hypercalcemia, hypercalciuria and urinary tract infection in the genesis of these calculi.

Key words: Spinal cord injury; Urolithiasis; Hypercalcemia; Hypercalciuria.

\section{Introduction}

THE prevention of urological complications is one of the most important objectives of successful rehabilitation of spinal cord injury patients. Often, the patient's life depends on the preservation of renal function. Urolithiasis is a well documented complication of spinal cord injury but its pathogenesis is not well understood. Several authors have attributed this to the immobility, hypercalciuria, urinary stasis, high urinary $\mathrm{pH}$ and urinary tract infection by urea splitting organisms. Comarr (I955) reported an incidence of renal calculi of 6.8 per cent and bladder calculi of 28 per cent in adult paraplegic patients. On the other hand Guttmann and Frankel (1969) and Smith et al. (1969) reported an incidence of renal calculi of about 2 per cent only. However, there is a paucity of references in the literature about urolithiasis in children with spinal cord injury.

The objective of this paper is to report a series of spinal cord injury children I to I 5 years old, with urolithiasis. An attempt will be made to analyse the role of hypercalcemia, hypercalciuria and urinary tract infection in urolithiasis in these patients.

\section{Materials and Methods}

Since January 1970 through December I977, 97 children (I-I5 years old) with spinal cord injury have been admitted at the Texas Institute for Rehabilitation and Research, Houston. Those 68 patients admitted before October I975 were studied retrospectively by exhaustive review of the medical records, while 29 patients admitted from November 1975 through December 1977 were studied prospectively.

The diagnosis of immobilisation hypercalcemia was made if one or more serum calcium determinations were above II $\mathrm{mg}$ per cent. The quantitative criteria for hypercalciuria was excretion of calcium above $200 \mathrm{mg} / 24$ hours in urine.

Similarly, urine cultures at the time of diagnosis of lithiasis were considered to be positive when one type of bacterial flora were isolated over $100000 \mathrm{col} / \mathrm{ml}$. If mixed flora were isolated, then a second culture was required to be certain that an adequate sample was taken.

Intravenous pyelograms were also available for study in all the patients.

${ }^{1}$ Supported in part by Rehabilitation Research and Training Center \#4 (RSA Grant 6-P-568I3/6-I6). 


\section{Results}

\section{Hypercalcemia}

Fourteen of 68 patients studied retrospectively had serum calcium levels higher than II $\mathrm{mg}$ per cent (See Table I). In the other I2 patients a serum calcium determination was not carried out. In the prospective study seven of 29 patients ( 24 per cent) were hypercalcemic.

Seventeen of $2 \mathrm{I}$ hypercalcemic patients were tetraplegic and four were paraplegic. There were 14 males and seven females within the 5-I 5 age range. Fifteen patients had complete and permanent paralysis, while six were incomplete lesions, and three of these had a good prompt neurological recovery.

\section{Urolithiasis}

Of the 97 children with spinal cord injury, 28 (28.7 per cent) developed urolithiasis. There were 20 boys and eight girls. In the group of 64 patients with normal serum calcium levels and 12 patients without serum calcium determinations, I 7 patients ( 22 per cent) formed calculi-I 4 in bladder ( 82 per cent) and two ( 12 per cent) in the kidney, one each in the renal pelvis and ureter.

In the group of 2 I patients with hypercalcemia, I I ( 52 per cent) developed calculi, seven in the kidneys and five in the bladder. One of these had bladder as well as renal calculi. Two patients developed bilateral staghorn calculi.

Twenty-four patients ( 86 per cent) were diagnosed of urolithiasis during the first year post injury, two were diagnosed between I2-15 months and two at 36 months following the onset of paralysis.

\section{Bacteriological Findings}

Of the I9 patients with bladder calculi, I 5 ( 79 per cent) were found to have a urine culture positive for Proteus rettgeri and/or Proteus mirabilis, one for Psuedomonas aeruginosa, two were positive for $E$. coli; while one had no growth of bacteria on repeated cultures (Table II). Of the nine patients with renal calculi, four

\section{TABLE I}

Distribution of urolithiasis by serum calcium levels and localisation of calculi

\begin{tabular}{|c|c|c|}
\hline $\begin{array}{l}76 \text { patients } \\
\text { Normocalcemic } \\
\text { 2I patients } \\
\text { Hypercalcemic }\end{array}$ & 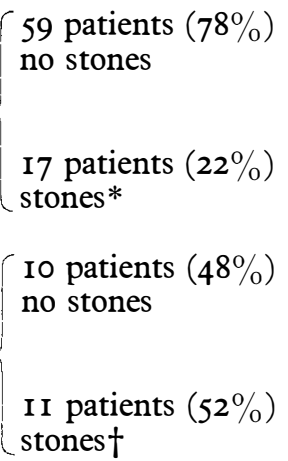 & $\left\{\begin{array}{c}\text { I4 bladder } \\
2 \text { kidney } \\
\text { I pelvis } \\
\text { I ureter }\end{array}\right.$ \\
\hline
\end{tabular}

* One patient had stones in the renal pelvis and bladder.

$\dagger$ One patient had stones in the kidney and bladder. 
cultures were positive for Proteus mirabilis/rettgeri, one was positive for Pseudomonas aeruginosa; while remaining four cultures were negative repeatedly. Two patients in prospective study developed hypercalcemia and renal calculi despite the fact that several cultures were sterile.

To study the effect of intermittent catheterisation on urolithiasis patients were divided in two groups (see Table III): (a) those admitted from January 1970 to December 1973-44 children had indwelling Foley catheter and did not undergo intermittent catheterisation programme. Twenty of these developed calculi and most of the calculi (85 per cent) were in the bladder, regardless of the level of serum calcium; and $(b)$ those admitted and treated from January 1974 through December 1977-53 patients were treated with intermittent catheterisation. Eight of 53 (I 5 per cent) developed calculi, five had calculi in the renal parenchyma and all were hypercalcemic.

TABLE II

Results of urine cultures

28 patients $\begin{cases}\text { I9 bladder stones }\left\{\begin{array}{l}\text { I5 Proteus Sp. }(79 \%) \\ \text { I Pseudomonas } \\ 2 \text { E. coli } \\ \text { I Negative }\end{array}\right. \\ 9 \text { kidney stones }\left\{\begin{array}{l}4 \text { Proteus }(44 \%) \\ \text { I Pseudomonas } \\ 4 \text { Negative* }\end{array}\right. \\ \hline\end{cases}$

* Prospective study.

\section{TABLE III}

Children with spinal cord injury and intermittent catheterisation programme -hypercalcemia and urolithiasis

I970-73 patients $\left\{\begin{array}{l}24 \text { No stones }(55 \%) \\ \text { I8 Normocalcemic } \\ 6 \text { Hypercalcemic } \\ 20 \text { Stones }(45 \%)\end{array}\left\{\begin{array}{l}\text { I4 Normocalcemic* }\left\{\begin{array}{l}\text { I2 bladder } \\ \text { I kidney } \\ \text { I renal pelvis } \\ \text { I ureter }\end{array}\right. \\ 6 \text { Hypercalcemict }\end{array}\left\{\begin{array}{l}5 \text { bladder } \\ 2 \text { kidney }\end{array}\right.\right.\right.$

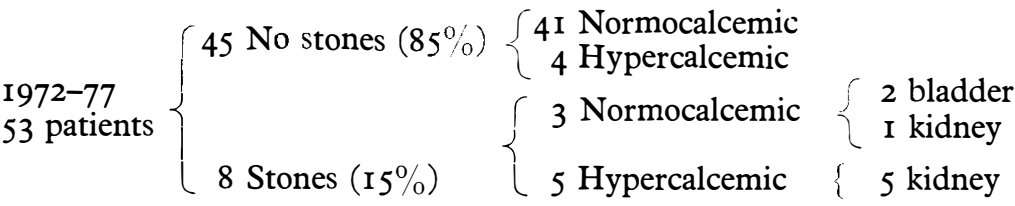

* One patient developed stone in the renal pelvis and bladder.

† One patient developed stone in the renal parenchyma and bladder. 
Correlation between hypercalcemia, hypercalciuria, urinary tract infection and urolithiasis

Nephrolithiasis: The incidence of nephrolithiasis in hypercalcemic patients was 33 per cent (seven out of 2 I patients) as compared to 3 per cent (two out of 76) in the normocalcemic group. This difference, we believe, might have been more significant had the normocalcemic retrospective group been studied as thoroughly as the prospective group with repeated serum calcium determinations. In the prospective study we identified four normocalcemic patients (serum calcium I0.6-I I mg per cent) two with bladder calculi and other two had renal calculi (see Fig. 2).

Nephrolithiasis was most frequently diagnosed during the first 20 weeks following injury, similar to the period of onset of immobilisation hypercalcemia. Five of the nine patients with hypercalcemia developed renal calculi during first 20 weeks following the injury, two during 20-50 weeks and two between I 2 and 17 months post trauma. Bur neither the onset of hypercalcemia nor the

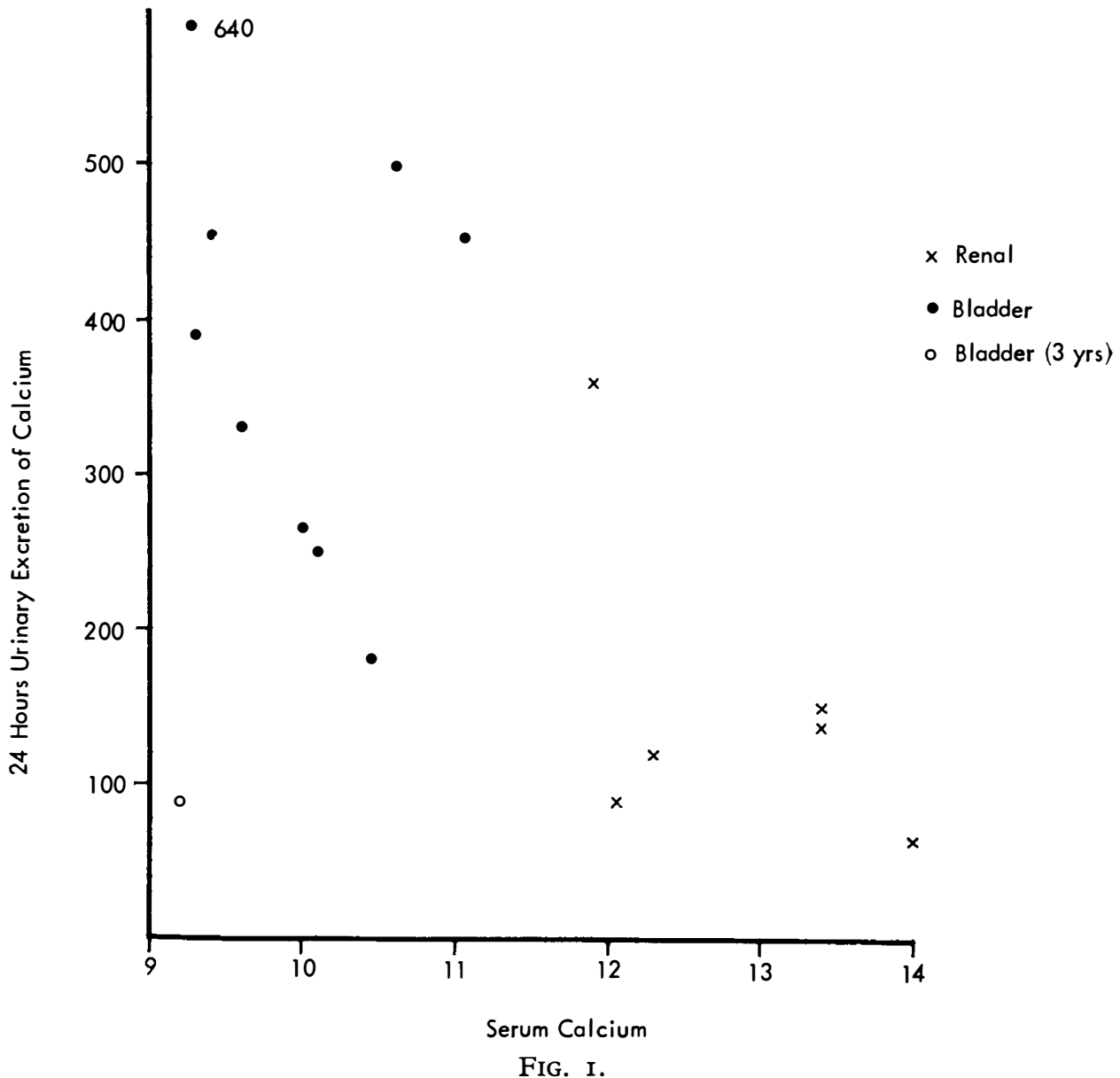

Serum calcium ( $\mathrm{mg} \%$ ) and 24 -hour urinary excretion of calcium $(\mathrm{mg})$ at the time of diagnosis of urinary lithiasis. 
onset of renal calculi could be documented accurately in the latter four patients. All calculi were located in the renal parenchyma or calyces. There was only one patient who developed calculus in the right pelvis and bladder at 3 years after the injury to the spinal cord. This patient also had chronic urinary tract infection with Proteus mirabilis and bilateral vesicoureteral reflux. Crystallographic analysis of her calculi indicated 70 per cent magnesium ammonium phosphate.

There also appears to be a good correlation between nephrolithiasis and the severity of hypercalcemia (Figs. I and 2). Of the five patients with serum calcium levels greater than $13 \mathrm{mg}$ per cent, four developed renal calculi and only one developed bladder calculi. Three other patients with serum calcium levels between I I.6-I $3 \mathrm{mg}$ per cent also developed renal calculi, while only two of the 20 patients with serum calcium levels between I0.6-II.5 mg per cent developed renal calculi. None of the 53 patients with serum calcium levels of $10.6 \mathrm{mg}$ per cent or below developed nephrolithiasis.

In the prospective study, there were two patients with hypercalcemia and repeated negative cultures of urine, who developed nephrolithiasis.

The data for crystallographic composition of renal calculi are available in only two patients, which showed 99 per cent calcium apatite and trace oxalite dihydrate. The nuclei of these also had the same composition.

Vesicolithiasis: Nineteen children with spinal cord injury developed bladder calculi, I 4 of these were normocalcemic. In the normocalcemic group of 76 patients I7 had lithiasis and I 4 of these had bladder calculi, as compared to five of hypercalcemic patients who developed calculi in the bladder. Although bladder calculi

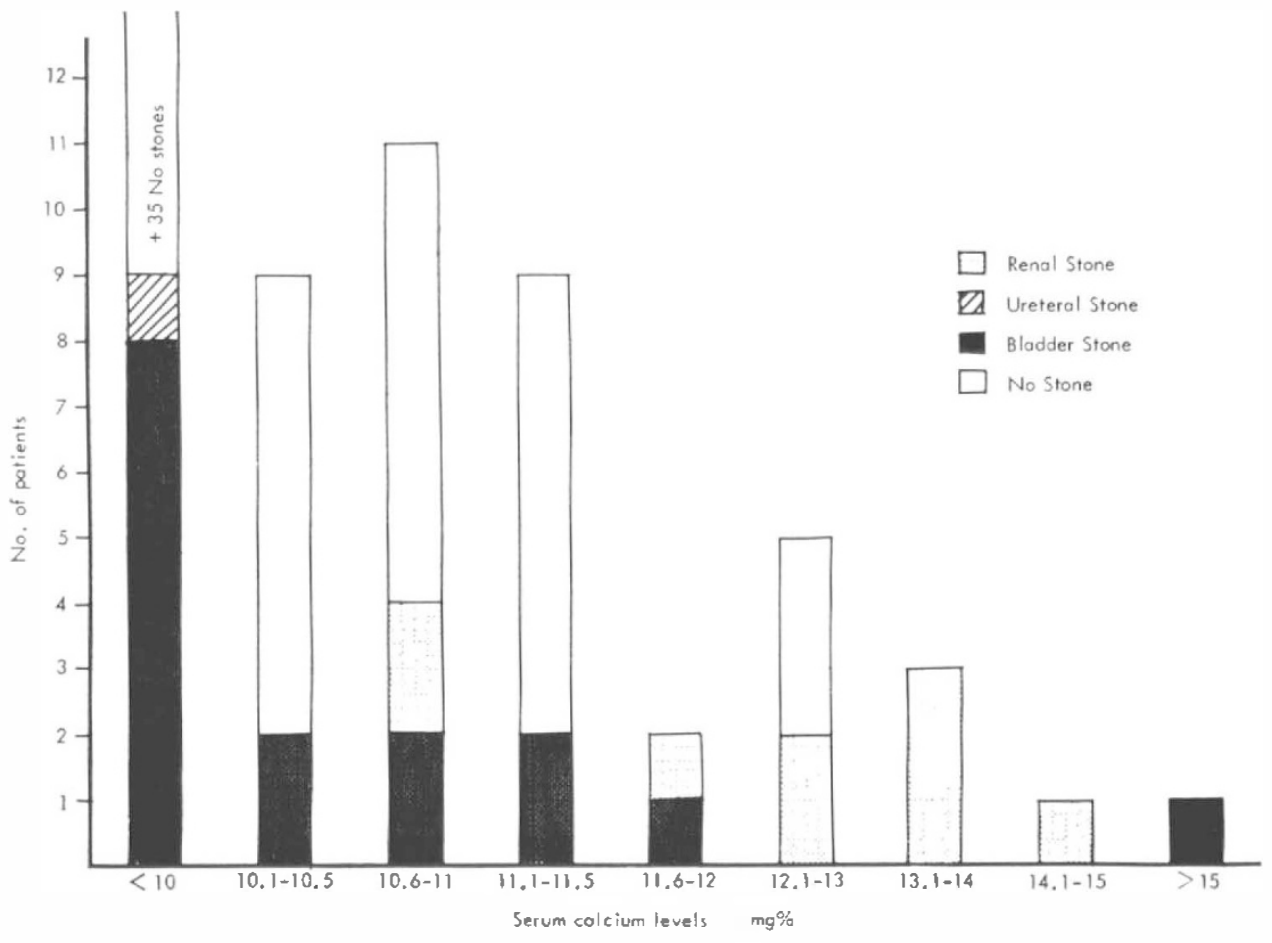

FIG. 2.

Distribution of localisation of urinary stones according to level of serum calcium. 
were present in both groups they seemed to be independent of the level of serum calcium (Fig. 2).

Eleven of the I9 patients with bladder calculi were diagnosed during the first 6 months, five between 6 and 12 months, and three were diagnosed between I 5-36 months. There seemed to be definite relationship between the time of diagnosis of bladder calculi and hypercalciuria, as hypercalciuria begins about Io days post paralysis, reaches maximum at Io weeks and persists at least 6 months. There was a significant difference between the 24-hour urinary excretion of calcium in patients with vesicolithiasis and nephrolithiasis (Fig. I).

Fifteen of the I9 patients ( 79 per cent) with bladder calculi had positive urine cultures for Proteus mirabilis or Proteus rettgeri at the time of the diagnosis of lithiasis (Table II).

The patients who were not treated by intermittentcatheterisation had incidence of 84 per cent bladder calculi while those treated by intermittent catheterisation had 25 per cent bladder calculi. Total incidence for urolithiasis in the two groups dropped from 45 to 15 per cent.

The crystallographic analysis of bladder calculi revealed calcium phosphate and magnesium ammonium phosphate.

\section{Discussion}

The formation of calculi in the kidneys and in the bladder is one of the main dangers accompanying spinal cord injuries. Several authors feel that the factors responsible for urolithiasis in these patients are-chronic urinary tract infection (especially urea splitting organisms), alkaline $\mathrm{pH}$, and most important urinary reflux (Kracht and Buscher, I974). Probably that is why prophylactic measures like intermittent catheterisation, acidification of urine, early mobilisation, forcing fluids and use of urinary bacteriostatic drugs have been widely recommended.

Several authors have reported an incidence of urolithiasis of 8 to 28 per cent in adult spinal cord injury patients (Comarr, I955; Buscher and Federschmidt, 1966; Stohr, I968; Marosszeky et al., 1973). Damanski (1963), Guttmann and Frankel (1969), Smith et al., (1969) and Pearman (1976) on the other hand have reported an incidence of urolithiasis of less than 2 per cent following spinal cord injury. From these data it is hard to calculate the incidence of urolithiasis in children and it is equally difficult to explain such wide range. In the present series, however, lithiasis occurred in 28 per cent children following spinal cord injury.

Freeman (1947) reported that calculus formation was directly related to hypercalciuria. The data reported by Comarr (1955) and Guttmann and Frankel (I969) indicate that the peak incidence of calculi occurred at $I \frac{1}{2}$ and 3 years following the spinal cord injury, suggesting that the formation of calculi might have started during this period of increased calcium excretion. In the present series eight of the ten patients with bladder calculi had hypercalciuria and positive urine cultures while only one of the six patients with nephrolithiasis was hypercalciuric. Though the number of patients is small to draw any broad sweeping conclusions, however, these findings do suggest that hypercalciuria, urinary tract infection and urinary statis play an important role in the genesis of bladder calculi only.

In children with hypercalcemia following spinal cord injury, probably concentrating ability of kidneys is impaired in addition to the general reduction in 
renal function since all patients with a serum calcium above $\mathrm{II} \cdot 4 \mathrm{mg} / \mathrm{dl}$ in this series had urine specific gravity less than $\mathrm{r} \cdot \mathrm{OIO}$ in spite of mild to moderate fluid restrictions. Also, all patients with hypercalcemia between II $\cdot 0$ and II 5 $\mathrm{mg} / \mathrm{dl}$ had a corrected creatinine clearance above $70 \mathrm{ml} / \mathrm{I} \cdot 73 \mathrm{~m}^{2} / \mathrm{min}$ and patients with serum calcium above $12.6 \mathrm{mg} / \mathrm{dl}$ had much lower creatinine clearances. Eight patients with serum calcium levels of I I $\cdot 8-12 \cdot 6 \mathrm{mg}$ per cent had a creatinine clearance below $50 \mathrm{ml} / \mathrm{I} \cdot 73 \mathrm{~m}^{2} / \mathrm{min}$. These data indicate that there is an inverse relationship between hypercalcemia and creatinine clearance. The impaired renal functions in hypercalcemic patients (specifically with increase of nonprotein bound calcium) will also tend to reduce urinary excretion of calcium (Smith and Williams, I97I) and possibly add to hypercalcemia. High concentrations of calcium within renal cells might under some circumstances lead to cellular death (Epstein, I97I) and form nidus for calcium precipitation and renal calculi. Once the nidus is formed, superimposed infection could participate in the formation of additional calculi but does not seem to be absolutely necessary. In the present series seven of the nine patients with renal calculi were hypercalcemic. Two of these hypercalcemic patients had repeated sterile cultures. These findings, though in a small patient population, suggest that hypercalcemia plays a promincnt role in nephrolithiasis in children with spinal cord injury.

Kracht and Buscher (1974) reported 29 patients with spinal cord injury and staghorn calculi. All had severe mixed infection, positive urine cultures for proteus, and the average time of onset was $I_{2} \frac{1}{2}$ years for tetraplegics and 4 years for paraplegics. In the present series there was only one patient with staghorn calculi.

Calculi from hypercalciuric patients have been reported to be primarily calcium oxalate (Nordin and Hodgkinson, I972) but, calculi in spinal cord injury patients during hypercalciuric phase have been found to be composed of calcium and magnesium phosphate (Damanski, 1963; Burr, 1978). The possible explanation for this difference in composition could be association of urinary tract infection in the latter group since calcium phosphate and magnesium ammonium phosphate calculi have been known to be associated with chronic infection with urea splitting organisms (Damanski, I963; Albanese, I 967). Burr (1978) suggested that in patients with chronic urinary tract infection with urea splitting organisms, calcium phosphate tends to precipitate when the $\mathrm{pH}$ of urine is high, while the precipitation of magnesium ammonium phosphate requires high concentration of ammonium ions. The composition of the renal calculi reported by Guttmann and Frankel (1969) and 98 per cent calculi reported by Burr (1978) had high concentrations of magnesium ammonium phosphate. The crystallographic findings of bladder and renal calculi in the present series are similar to those reported by other authors (Damanski, I963; Guttmann and Frankel, 1969; Burr, 1978) but the two hypercalcemic patients with renal calculi and sterile urine had 99 per cent calcium apatite.

The incidence of urolithiasis in children treated with intermittent catheterisation technique in this series was significantly lower than those treated by continuous Foley drainage ( 15 per cent in the former group and 45 per cent in the other group). But, these figures are definitely higher than those reported by Guttmann and Frankel (1969) and Pearman (1977), or less than 2 per cent.

\section{Conclusion}

I. Pathogenesis of nephrolithiasis in children with spinal cord injury is directly related to immobilisation hypercalcemia. 
2. Pathogenesis of vesicolithiasis is related to hypercalciuria, urinary stasis and urinary tract infection by urea splitting bacteria. Hypercalciuria enhances the formation of calculi. It needs to be demonstrated if hypercalciuria in the absence of urinary tract infection could form calculi.

3. By intermittent catheterisation we have been able to reduce the frequency of urinary tract infection and incidence of urolithiasis.

4. Incidence of urolithiasis is higher in the children than the adults following spinal cord injury.

\section{SUMMARY}

Since January I970 through December I977, 97 children (I-I5 years old) with spinal cord injury have been admitted at the Texas Institute for Rehabilitation and Research, Houston. Twenty-eight children (28 per cent) developed urolithiasis and 86 per cent of these developed this complication during the first year following the injury. Seventeen patients with calculi were normocalcemic while I I were hypercalcemic. Nineteen of 28 patients had bladder calculi, while other nine had calculi in the renal parenchyma or calyces. 80 per cent of patients with bladder calculi had urine cultures positive for Proteus mirabilis, Proteus rettgeri, Pseudomonas aeruginosa and E. coli. Four of nine patients with renal calculi had sterile urine on repeated cultures. Only I 5 per cent of patients treated with intermittent catheterisation developed calculi while 45 per cent of patients treated with indwelling Foley catheter developed this problem. Nephrolithiasis in these patients seemed to be related to hypercalcemia. Vesicolithiasis was related to hypercalciurea, urinary stasis and urinary tract infection.

\section{RÉSUMÉ}

Entre janvier I 970 et decembre I977, 97 enfants de I à I 5 ans ayant souffert dommage de la moëlle épinière ont été hospitalisés au "Texas Institute for Rehabilitation and Research" à Houston. Vingt-huit enfants $(28 \%)$ ont développé urolithiase et 86 pour cent de ceux-ci ont développé cette complication pendant les premiers douze mois suivant l'accident. Dix-sept malades avec calculs étaient normocalcémiques et onze étaient hypercalcémiques. Dix-neuf des 28 malades avaient des calculs dans la vessie tandis que les neuf autres avaient les calculs dans le parenchyme ou les calices rénaux. Quatre-vingt pour cent des malades avec calculs de la vessie avaient des cultures positives pour Proteus mirabilis, Proteus rettgeri, Psuedomonas aeruginosa and E. coli. Quatre des neuf malades avec calculs du rein avaient une urine stérile après plusieurs cultures. Seulemant 15 pour cent des malades traités avec une cathéterisation intermittante ont développé des calculs tandis que 45 pour cent des malades traités avec Foley catheter permanent ont développé ce problème. Néphrolithiase dans ces cas semble être connectée à la hypercalcémie. Vesicolithiase est connectée à l'hypercalciurée, stase de l'urine et à l'infection du systéme urinaire.

\section{ZUSAMMENFASSUNG}

Im Texas Istitut of Rehabilitation and Research wurden zwischen Januar I 970 und Dezember 1977 siebenundneunzig Kinder in Alter von ein bis fünfzehn Jahren mit Rückenmarkverletzungen aufgenommen. Achtundzwanzig Kinder $(28 \%)$ entwickelten Urolithiasis, $86 \%$ davon im ersten Jar nach der Verletzung. Siebzehn Patienten mit Steinen hatten einen normalen Blut-Kalziumspiegel, elf waren hyperkalzämisch. Neunzehn der achtundzwanzig Patienten hatten Nierensteine, bei den anderen neun fanden sich Steine in renalen Parenchym oder in den Calices. Urinkulturen von $80 \%$ der Patienten mit Blasensteinen waren positiv für Proteus mirabilis, Proteus rettgeri, Pseudomonas aeruginosa und E. coli. Vier der neun Patienten mit Nierensteinen zeigten in wiederholten Kulturen sterilen Urin. Im Gegensatz zu I 5\% der Patienten, die gelegentlich katheterisiert wurden, entwickelten $45 \%$ der Patienten mit Dauerkatheter nach Foley Steine. Nephrolithiasis in diesen Patienten schien eine Folge der Hyperkalzämie zu sein. Vesicolithiasis trat in Verbindung mit Hyperkalzurie, Harnverhalten, und Infection der Harnwege auf. 


\section{REFERENCES}

Albanese, A. A. (1977). Bone Loss: Causes, Detection and Therapy, pp. 35. Alan R. Liss, Inc., New York.

BURR, R. G. (I972). Urinary calcium, magnesium, crystals and stones in paraplegia. Paraplegia, Io, 56.

BURR, R. G. (I978). Urinary calculi composition in patients with spinal cord lesions. Arch. Phys. Med. Rehabil., 59, 84.

Buscher, H. K. \& FEDERSCHMIDT, K. (1966). Die Bedeutung des vesico-ureteralen Refluxes. Fortschr. Med., Wschr, 84, 315.

COMARR, E. (I955). A long-term survey of the incidence of renal calculosis in paraplegia. F. Urology, 74, 447 .

DAmANSKi, M. (1963). Stone disease in paraplegia. Paraplegia, I, I49.

EPSTEIN, F. H. (I97I). Calcium nephropathy in disease of the kidney. In M. B. STrauss, and G. WeLt (eds)., Diseases of the Kidney, 2nd ed., p. 903. Boston, Little, Brown and Co., New York.

Freeman, L. W. (1949). The metabolism of calcium in patients with spinal cord injury. Ann. Surg., 129, I77.

GuTTMAN, L. \& FRANKEL, H. L. (1969). Value of intermittent catheterization in the early management of traumatic paraplegia and tetraplegia. Paraplegia, 4, 63.

KRACHT, H. \& BUSCHER, H.-K. (I974). Formation of staghorn calculi and their surgical implications in paraplegics and tetraplegics. Paraplegia, 12, 98.

Marosszeky, J. E., FARNSWORTH, R. H. \& JONES, R. F. (I973). The indwelling urethral catheter in patients with acute spinal cord trauma. Medical fournal of Australia, 2, 62.

Nordin, B. E. C. \& Hodgkinson, A. (I972). Urinary tract calculi. In D. BlACK (ed.), Renal Disease, 3rd ed., p. 759. Blackwell, Oxford.

Pearman, J. W. (I976). Urological follow-up of 99 spinal cord injured patients initially managed by intermittent catheterization. British fournal of Urology, 48, 297.

SMith, L. H. JR. \& Williams, H. E. (I97I). Kidney stones. In M. B. STrauss and G. Welt (eds.), Diseases of the Kidney, 2nd ed., p. 973. Little, Brown \& Co., New York.

Smith, P. H., Cook, J. B. \& Robertson, W. G. (1969). Stone formation in paraplegia. Paraplegia, 7, 77.

STÖHR, CHR. (I968). Verhütung von Steinbildungen in Harnsystem der Querschnit gelähtmten. Münch. Med. Wschr., 179, 2308. 